\title{
CORRESPONDENCE
}

\section{Professor Emeritus Swarna Jayaweera: An appreciation}

\author{
W. A. De Silva ${ }^{1}$ and Chandra Gunawardena ${ }^{2 *}$ \\ ${ }^{I}$ Emeritus Professor in Education, University of Colombo, Colombo, Sri Lanka. \\ ${ }^{2}$ Emeritus Professor in Education, Open University of Sri Lanka, Nawala, Sri Lanka.
}

It is with great sorrow and a deep sense of gratitude this appreciation is penned for Professor Swarna Jayaweera, who left us several months ago.

Thousands of students, at both undergraduate and postgraduate levels, at the University of Peradeniya, and the Faculties of Education and Graduate Studies, University of Colombo, who benefitted from her teaching, will undoubtedly recollect with gratitude the remarkable inputs the Professor made to their academic and professional development. As an academic who had studied for her undergraduate, Masters and Doctoral degrees in the University of London, she was an unparalleled leader in the field of education.

She started her career as a lecturer in Education at the University of Peradeniya where she served for a number of years until she was appointed as the first Chair Professor of Education in the University of Colombo, when the Colombo section of the University of Ceylon was elevated to the level of an independent and separate university. Department of Education of the University of Colombo was to be the nucleus of the future Faculty of Education and Professor Jayaweera played a very significant part in planning out the structure of the Faculty. The success and progress of the Faculty owe a lot to her skillful foresight. It is noteworthy that Professor Jayaweera made a significant effort to transmit these qualities to the academics and students who worked with her in the university. It was in recognition of these endeavours that the University of Colombo and the Open
University of Sri Lanka awarded her Doctor of Letters degrees.

In recognition of her eminence in the field of education, Prof. Jayaweera was appointed as an Adviser/Consultant to several international organisations, such as UNESCO and UNICEF, UNIDO, ESCAP, Asian Development Bank, and also as a member of the Advisory groups on education in Asia by the University of London and the University of Sussex. In addition to the above, she also functioned as a consultant to organisations such as IRDP, SIDA, NORAD, CIDA, ILO, IFAD, GTZ, World Bank, UNFPA and JICA.

Prof. Jayaweera's expertise was recognised when she was also appointed as a Member of several national organisations, including the National Academy of Sciences of Sri Lanka, the Vice Chairperson-National Education Commission, National Science and Technology Council, Monitoring Committee, SAARC Social Charter-Plan of Action and the Standing Committee on Education of the University Grants Commission.

Professor Jayaweera's contribution as the Vice Chairperson of the National Education Commission is highly commendable. She initiated 23 research studies on identified issues in Sri Lankan education and published them separately and as a composite volume. Through these studies, the Commission was able to make significant changes in the education system.

"Corresponding author (ggunawardena@hotmail.com) 
When the subject of History was deleted from the secondary school curriculum, she, along with a group of other scholars, protested against it and finally got it reinstated in the curriculum. When the Ministry of Education started scrapping small schools, she was able to anticipate its harmful results on the poor population in the rural areas and stood against it. She pointed out that it was a direct blow on the educational opportunities of a considerable section of the population and demanded that the Ministry reviews the policy of cutting down expenditure at the expense of the education of the poor people.

Prof. Jayaweera's dedication and contribution to the area of gender is unrivalled. She was a Founder member of the Centre for Women's Research and persevered to highlight research on women, multi-faceted issues faced by them and to seek funding for publication, dissemination of research findings and necessary action. This organisation motivated many young scholars to undertake gender studies from a feminist view point and they have contributed to the development of feminist research and action in Sri Lanka in a variety of fields.

At national level, her contribution to both fields of education and gender has been recognised by organisations such as ZONTA International, Sarvodaya, SANASA, Coalition for Educational Development, and by the award of national honours of Kala Keerthi and Deshabandu.

What is noteworthy is that Prof. Swarna Jayaweera did not engage in research or other academic pursuits to improve her credentials but to make a contribution to the development and improvement of the situation in the country and society in general. Even though she is no longer there to work with us, there is much that we can learn from her and to emulate her in our own areas of work. 